\title{
Protein Dr1
}

National Cancer Institute

\section{Source}

National Cancer Institute. Protein Dr1. NCI Thesaurus. Code C29571.

Protein Dr1 (176 aa, $\sim 19 \mathrm{kDa}$ ) is encoded by the human DR1 gene. This protein is involved in the repression of gene transcription. 